\title{
CAEC (COMMUNITY OF ACTIVE ENGLISH COMMUNICATION)- BASED EMPOWERMENT OF LAKE TEMPE WAJO TOURISM REGIONAL COMMUNITIES
}

\author{
Syahrun Adzim ${ }^{*}$ \\ Amiruddin ${ }^{2}$ \\ 1,2 Institut Agama Islam As'adiyah Sengkang, Sengkang, Indonesia \\ syahrunadzim@gmail.com ${ }^{\left.1^{*}\right)}$ \\ amiruddin1@gmail.com ${ }^{2)}$
}

Keywords: [Tempe Lake,

Tourism, CAEC]

Published by:

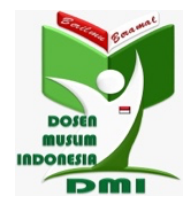

Abstract: South Sulawesi's Lake Tempe is a popular tourist site. Many foreigners, both locally and internationally, visit Lake Tempe. The quality of the guide's service has a significant impact on the smoothness and comfort of travel in Tempe. As a result, a training and mentoring program for foreign-language tourism performers in the Tempe Lake area is required. The PKM program is carried out in stages: (1) PKM participant selection; (2) PKM briefing participants; (3) survey site; (4) PKM program socialization; (5) debriefing tourist actors; and (6) twice-weekly training and mentorship for three months. In total, 25 meetings were held to provide training and mentorship. The training team enhances the vocabulary at the start of the training, and subsequently, the material and speaking are intensified by the team. The assessment's findings revealed a significant increase: (1) There were three people in the very good group, 25 in the good category, and two in the bad category when it came to vocabulary ability. (2) There are 26 persons who are classified as good at tenses, and just four people who are classified as less good. (3) In terms of speaking skill, four people were rated as very good, 25 were rated as good, and one was rated as less good.

Copyright (C) 2021 The Author(s)

This article is licensed under CC BY 4.0 License (cc) BY 


\section{Introduction}

Lake Tempe is one of the tectonic lakes in Indonesia. Lake Tempe is referred to as an ancient lake formed due to natural geological processes that are estimated to be the same age as the plains of South Sulawesi (Giesen, 1994; Nontji, 1994; Waluyo et al., 1977; Caldwell \& Lillie, 2004; Nasrul, 2016). This lake is located in the province of South Sulawesi. There are 23 rivers that flow into and empty into this lake, which has an abundance of freshwater fish. In addition to being a tourist area, Lake Tempe is also a source of livelihood for local residents. Lake Tempe, which is located in Wajo Regency, South Sulawesi, is one of the most potential tourist attractions to visit. The natural tourism panorama of Lake Tempe is very interesting for tourists who visit (Irianti \& Sartika, 2016). With a variety of uniqueness and natural beauty that are presented, Lake Tempe is one of the most unique tourist objects owned by the Indonesian people. But so far, there has been no new breakthrough in the development of Lake Tempe tourism. Efforts to develop the Lake Tempe tourist area are being carried out because they will have an impact on the economy of the people in the area. A good tourist attraction area will attract tourists to visit the place both from inside and outside. Though it has already been visited by tourists from outside and within the country, development strategies must continue to be carried out to increase the number of visitors so that Lake Tempe attractions can become a tourist destination that is visited by many tourists (Upe \& Yani, 2019; Aprisa \& Patahuddin, 2019; Fadillah et al., 2021).

The purpose of this scientific paper is to discuss the strategy for developing the Tempe Lake area as a tourist attraction in South Sulawesi. The strategy for developing the Lake Tempe area based on 3E (education, environment, and entrepreneurship) (Berger et al., 2007; Rimmington et al., 2009; Arend et al., 2015; Julifa et al., 2015; Abdelmaged, 2021; Viveiros et al., 2021) is a new breakthrough in realizing independent tourism in the Wajo district. The type of writing in this scientific paper is library research (Nicotera et al., 2001; Aharony, 2006; George, 2008; Wijayanti, 2014; Sesagiri Raamkumar, 2015; Winchester \& Salji, 2016; Kasdi \& Wijayanti, 2017; Sari \& Asmendri, 2020). The data collection technique used is to collect secondary data related to the formulation of the problem obtained from various references and then analyze it descriptively and qualitatively (Nassaji, 2015; Kim et al., 2017; Graneheim et al., 2017). The concept of the Lake Tempe area development strategy based on 3E (Education, Environment, and Entrepreneurship) is through the provision of facilities that will provide education to the public and visiting tourists, such as the provision of meeting halls and Atakkae Balls. Meanwhile, the strategy for developing environmental-based tourism in Temper Lake is carried out with a socio-cultural approach that emphasizes the importance of understanding the social and cultural aspects of local communities in environmental management. as well as a business-based tourism development strategy by providing a business center for the community. The business center in question is based on the "Pabbalu-balu" concept, which is the Lake Tempe culinary and souvenir center. In addition, the provision of infrastructure, such as lodging, with the design concept of "panggung" houses and piers, is rich in natural elements (Yunus, 2012; Amalia, 2014; Beddu et al., 2018; Husnaini et al., 2021).

\section{Implementation Method}

The PKM program is divided into seven stages: (1) recruitment/selection of PKM participants; (2) debriefing students who participated in PKM twice; (3) 
survey/observation of PKM locations; (4) socialization of the PKM program; (5) debriefing community and tourism actors who participated in the PKM program; (6) preparation of practical guidebooks; and (7) training and mentoring for three months by students and TJB Language and Com Centre.

Language classes are organized into groups based on the services that are provided on a daily basis. The training will be held twice a week for three months, with each meeting lasting six hours. Vocabulary, tenses, and speaking are the training resources. During field service activities, participants receive assistance.

\section{Results and Discussion}

We assessed the participants' English skills in each group prior to the training and mentorship. The findings revealed that (1) $80 \%$ of the participants lacked sufficient vocabulary, as they only used simple words when providing services to tourists; and (2) up to 98 percent of the participants lacked the necessary tenses/grammar skills to carry out their profession, as tourism actors use irregular sentences in every conversation. Based on these insights, the field supervisor established a training and mentorship strategy with the students and the TJB Language and Com Center team. The initial training aimed to improve the participants' vocabulary abilities, after which the team focused on tenses, syntax, and speaking materials. The team issued a practical manual with terminology for offering tourist services to the participants in order to improve their vocabulary abilities.

Because the content learned in training is immediately implemented by participants in their profession, training and mentorship are beneficial in enhancing the English language abilities of tourist actors. The training, which takes place where the tour operator works, makes the experience more enjoyable and relevant. This helps the PKM team to quickly correct any misunderstandings in the use of English among the participants.

The results of the mid-assessment show that (1) in vocabulary ability, as many as 18 people are in a good category, 11 people are in the poor category, and 1 person is in a bad category. (2) In tensile ability, as many as nine people are categorized as "good" and twenty people are categorized as "poor." (3) In speaking ability, as many as 25 people are in the "Good" category and 5 people are in the "Poor" category. The increase in the competence of participants is quite significant, and this is evidenced by the results of the final assessment showing that (1) in vocabulary ability, as many as 3 people are in the Very Good category, 25 people are in a Good category, and 2 people are in the Poor category. (2) On the ability of tenses, as many as 26 people are in the good category, and four people are in the poor category. (3) In speaking ability, there are 4 people in the very good category, 25 people in the good category, and 1 person in the poor category.

\section{Conclusions}

1. The PKM program can help tourism actors (bike renters, kusircidomo, and speedboat drivers) in Gili Trawangan improve their English abilities (vocabulary, tenses, and speaking) as well as their capacity to provide tourist services.

2. The PKM software can help travelers communicate more comfortably with tourism actors on Lake Tempe, such as bike renters, kusircidomo, and speedboat drivers. 
3. The PKM program has the potential to boost the income of tourism players on Lake Tempe, such as bicycle renters, kusircidomo, and speedboat operators.

\section{Refereces}

Abdelmaged, M. A. M. (2021). Implementation of Virtual Reality in Healthcare, Entertainment, Tourism, Education, and Retail Sectors.

Aharony, N. (2006). The use of deep and surface learning strategies among students learning English as a foreign language in an Internet environment. British Journal of Educational Psychology, 76(4), 851-866.

Amalia, A. A. A. A. (2014). Karakteristik Arsitektur Rumah Adat Wajo Di Kompleks Miniatur Budaya Sulawesi Selatan Benteng Sombaopu Makassar. Teknosains: Media Informasi Sains Dan Teknologi, 8(2), 227-240.

Aprisa, Y., \& Patahuddin, P. (2019). Tradisi Maccera'Tappareng di Danau Tempe 20002018. PATTINGALLOANG, 6(1), 98-112.

Arend, R. J., Sarooghi, H., \& Burkemper, A. (2015). Effectuation as ineffectual? Applying the 3E theory-assessment framework to a proposed new theory of entrepreneurship. Academy of management Review, 40(4), 630-651.

Beddu, S., Martosenjoyo, T., Latief, M. S., \& Ishak, R. A. (2018). Perubahan Bentuk Fasade Arsitektur Rumah Panggung Bugis di Sulawesi Selatan (Studi tentang Perubahan Bentuk Lego-Lego atau Teras). In Prosiding Seminar Ilmiah Nasional Sains dan Teknologi (Vol. 4, pp. 25-34).

Berger, H., Dittenbach, M., Merkl, D., Bogdanovych, A., Simoff, S., \& Sierra, C. (2007). Opening new dimensions for e-tourism. Virtual Reality, 11(2), 75-87.

Caldwell, I., \& Lillie, M. (2004). Manuel Pinto's inland sea: Using palaeoenvironmental techniques to assess historical evidence from southwest Sulawesi. In Quaternary Research in Indonesia (pp. 259-271). CRC Press.

Fadillah, I., Mone, A., \& Riskasari, R. (2021). Pariwisata Dalam Meningkatkan Kunjungan Destinasi Wisata Di Provinsi Sulawesi Selatan. Kajian Ilmiah Mahasiswa Administrasi Publik (KIMAP), 2(1), 353-367.

George, M. W. (2008). The elements of library research. Princeton University Press.

Giesen, W. (1994). Indonesia's major freshwater lakes: A review of current knowledge, development processes and threats. Internationale Vereinigung für Theoretische und Angewandte Limnologie: Mitteilungen, 24(1), 115-128.

Graneheim, U. H., Lindgren, B. M., \& Lundman, B. (2017). Methodological challenges in qualitative content analysis: A discussion paper. Nurse education today, 56, 29-34.

Husnaini, A. S., Rachmawati, M., \& Santosa, H. R. (2021). Comparative Study of Traditional House Forms in Indonesia: Loloan and Bugis Stilt Houses. International Journal of Multidisciplinary Research and Publications (IJMRAP), Volume 4, Issue 2, pp. 35-39. 
Irianti, I., \& Sartika, R. A. (2016). Strategi Pengembangan Kawasan Danau Tempe Berbasis $3 e$ (Education, Environment And Entrepreneur) Menuju Pariwisata Mandiri (Doctoral dissertation, Muhammadiyah University Makassar).

Julifa, J., Goestina, G., \& Hasnih, H. (2015). Pemberdayaan Pemuda Pesisir melalui Tamparang House Berbasis 3e (Education, Environment, Entrepreneur) Menuju Masyarakat Sejahtera (Doctoral dissertation, Muhammadiyah University Makassar).

Kasdi, K., \& Wijayanti, D. N. (2017). Pembelajaran Bahasa Inggris Efektif Melalui Lagu Anak-anak untuk Siswa Madrasah Ibtidaiyah. ELEMENTARY: Islamic Teacher Journal, 4(1).

Kim, H., Sefcik, J. S., \& Bradway, C. (2017). Characteristics of qualitative descriptive studies: A systematic review. Research in nursing \& health, 40(1), 23-42.

Nasrul, R. Y. (2016). Keanekaragaman ikan air tawar di perairan danau Tempe (Doctoral dissertation, Universitas Islam Negeri Alauddin Makassar).

Nassaji, H. (2015). Qualitative and descriptive research: Data type versus data analysis. Language teaching research, 19(2), 129-132.

Nicotera, C. L., Shibley Jr, I. A., \& Milakofsky, L. K. (2001). Incorporating a substantial writing assignment into organic chemistry: library research, peer review, and assessment. Journal of Chemical Education, 78(1), 50.

Nontji, A. (1994). The status of limnology in Indonesia. Internationale Vereinigung für Theoretische und Angewandte Limnologie: Mitteilungen, 24(1), 95-113.

Rimmington, M., Williams, C., \& Morrison, A. (2009). Entrepreneurship in the hospitality, tourism and leisure industries. Routledge.

Sari, M., \& Asmendri, A. (2020). Penelitian Kepustakaan (Library Research) dalam Penelitian Pendidikan IPA. Natural Science: Jurnal Penelitian Bidang IPA Dan Pendidikan IPA, 6(1), 41-53.

Sesagiri Raamkumar, A., Foo, S., \& Pang, N. (2015, May). Rec4LRW-Scientific paper recommender system for literature review and writing. In Proceedings of the 6th international conference on applications of digital information and web technologies (pp. 106-120).

Upe, A., \& Yani, A. (2019). Pemberdayaan Masyarakat Kawasan Rumah Terapung Danau Tempe untuk Meningkatkan Potensi Ekowisata Berbasis Komunitas. Jurnal Pengabdian Kepada Masyarakat (JurDikMas) Sosiosaintifik, 1(1), 30-37.

Viveiros, L. C., Pereira, A. I., Peroni, J. V., Fachada, I., \& Gonçalves, E. (2021). Natureza Virtual: Enhancing Ecosystem Awareness by Using Virtual Reality in Educational Tourism. Augmented Reality and Virtual Reality: New Trends in Immersive Technology, 291.

Waluyo, S., Feryanto, A., \& Haryanto, T. (1977). Ilmu Pengetahuan Sosial. Grasindo. 
Wijayanto, R. (2014). Perancangan Animasi Interaktif Pembelajaran Bahasa Inggris Untuk Kelas 2 Pada Mi Nurul Falah Ciater. EVOLUSI: Jurnal Sains dan Manajemen, 2(1).

Winchester, C. L., \& Salji, M. (2016). Writing a literature review. Journal of Clinical Urology, 9(5), 308-312.

Yunus, P. P. (2012). Makna simbol bentuk dan seni hias pada Rumah Bugis Sulawesi Selatan. Panggung, 22(3). 